\title{
The experience of pilgrimage in the Roman Empire: communitas, paideiā, and piety-signaling
}

Book or Report Section

Published Version

Creative Commons: Attribution-Noncommercial-No Derivative Works 4.0

Open Access

Rutherford, I. (2020) The experience of pilgrimage in the Roman Empire: communitas, paideiā, and piety-signaling. In: Gasparini, V., Patzelt, M., Raja, R., Rieger, A.-K., Rüpke, J. and Urciuoli, E. (eds.) Lived Religion in the Ancient Mediterranean World. De Gruyter, Berlin, Germany, pp. 137156. ISBN 9783110557572 doi:

https://doi.org/10.1515/9783110557596 Available at https://centaur.reading.ac.uk/90126/

It is advisable to refer to the publisher's version if you intend to cite from the work. See Guidance on citing.

To link to this article DOI: http://dx.doi.org/10.1515/9783110557596

Publisher: De Gruyter

All outputs in CentAUR are protected by Intellectual Property Rights law, including copyright law. Copyright and IPR is retained by the creators or other copyright holders. Terms and conditions for use of this material are defined in the End User Agreement. 


\section{CentAUR}

Central Archive at the University of Reading

Reading's research outputs online 


\title{
Ian Rutherford
}

\section{The experience of pilgrimage in the Roman Empire: communitas, paideiā, and piety-signaling}

\begin{abstract}
Pilgrimage of various types is well attested in the pre-Christian religions of the Roman Empire, but there is comparatively little evidence for the personal experiences of pilgrims. Some recent studies have argued that typical pilgrims of this period were members of the intellectual elite highly versed in literary culture (paideia) who saw sacred places as museums of Greek culture. In this paper, I try to reconstruct what we can about the experience of pilgrimage in early Roman Empire, looking at three cases studies:

a. Philo's somewhat idealized account of Jewish pilgrimage to Jerusalem, which stresses intense common feeling (or communitas, to use Victor Turner's term) between participants;

b. Pilgrimage to the oracle of Apollo at Claros, to which cities of Asia Minor and elsewhere sent sacred delegations, largely made up choirs of children who performed hymns at the sanctuary. It may be suggested that the experience of the pilgrimage was in large part an educative one - learning about Greek culture and learning how to behave in public; it might even be seen as a sort of rite of passage.

c. The healing-pilgrimages of Aelius Aristides to Pergamum and elsewhere. Aristides' experience at Pergamum is full of paideia, though that was not the primary motivation, and it sometimes approaches communitas, though in the end the presence of other people tends to serve the purpose of an audience and foil for his own brilliance. Key aspects of his experience seem to be: a) suffering and b) a feeling of closeness to the god, sometimes bordering on identification with him.
\end{abstract}

\section{Introduction}

Any enquiry into the experience of pilgrimage in the Ancient World faces three initial problems: ${ }^{1}$

1 The paper excludes Christian pilgrimage (which is outside my sphere of competence).

Note: Much of this paper was written while I was a visiting senior fellow at ANAMED in Istanbul, spring 2017.

๖ Open Access. ( 2020 lan Rutherford, published by De Gruyter. (cc) BY-NC-ND This work is licensed under a Creative Commons Attribution-NonCommercial-NoDerivatives 4.0 International License.

https://doi.org/10.1515/9783110557596-008 
1. The definition of pilgrimage. Over the last two decades, some scholars have begun to use the term "pilgrimage" in the context of Mediterranean polytheism, while others have resisted it. ${ }^{2}$ My view is that the use of the term is justifiable, as long as we are aware of what we mean by it. A useful general definition seems to me that of Joy McCorriston: "Pilgrimage is a journey to a sacred place to participate in a system of sacred beliefs" (McCorriston 2011, 19). ${ }^{3}$ Within this general concept, we need to distinguish pilgrimages of different types, e.g. healing pilgrimages or pilgrimages of initiation. But however we define the concept, there will still be grey areas: for example, should we think of the audience of Pausanias' Periegesis as tourists, an educated elite, or pilgrims (see Elsner 1997)? When people leave graffiti on Egyptian monuments, e.g. in the Theban Tombs, should those be considered pilgrimage or tourism or religious tourism? And can the term "pilgrimage" be applied even if the journey is only a few kilometres, such as that from Antioch in Pisidia to the sanctuary of Men Askaenos on the hill $5 \mathrm{~km}$ SE of the city (see Labarre and Tasliahan 2002)?

2. The definition of "experience". The word is ambiguous, covering either i. "what happens to someone", or ii. someone's subjective experiences, i.e. how experience in the first sense feels. The second is of course harder to establish, given the nature of our sources.

3. Evidence. In general, pilgrimage leaves little evidence, considering its likely volume (see Rutherford 2013, 17). Some important pilgrimage traditions are almost undocumented, for example that relating to the festival of Artemis at Ephesos (Kötting 1950; Oster 1990; Elsner 1997). What evidence does survive tends to fall into two categories: i. literary accounts, and ii. inscriptions of various sorts. Inscriptions are usually simple public records of visitation, including little if any information about the experience of participants (at least in the sense of "subjective experience"). Literary accounts, where we have them, are a much better source for human experience, but they raise other problems: do they give us an accurate account of the "lived" experience of pilgrims, or should we think of them as shaped and determined by literary tradition?

In recent decades scholars have begun to discuss pilgrims' experience. Matthew Dillon has assembled some relevant evidence for Greek sanctuaries (Dillon 1997, 204-227). In the Seeing the Gods volume the word "experience"

2 Those using the term include Jas Elsner, Matthew Dillon and Troels Myrop Kristensen. For resistance to the term see Rutherford 2013, 12-14; recent criticism has come from Price 2012, 8 n. 36 and now Bremmer 2017.

3 I owe the citation to Kristensen 2012, 107 n. 1. 
(noun or verb) is used well over one hundred times (Elsner and Rutherford 2005). Jas Elsner, Marco Galli and Alexia Petsalis-Diomides have looked particularly at experience of different forms of pilgrimage in the Second Sophistic (Elsner 1992; Galli 2005; Petsalis-Diomides 2005; 2010).

Here are some of the basic areas of experience that we find in most forms of pilgrimage, including Greco-Roman pilgrimage:

- Enhanced religious experience. The sacred place is often regarded as somewhere where access to the deity is easy, often because the deity is supposed to have manifested her-/himself there, or performed some miracle. Strabo (Geog. 8.6.15) talks of the epiphaneiā ("tendency to reveal himself") of Asclepius at Epidauros. Aelius Aristides has a vivid dream of his encounter with Asclepius at Pergamum ("it seemed as if I touched him": Sacred Tales 2.32-33). Thessalos of Tralles imagined himself as actually meeting Amun at Egyptian Thebes (Totti 1985, no. 5). ${ }^{4}$

- Obligatory ritual scripts. Pilgrims are required to perform certain key ritual acts in the sanctuary, such as making an offering, taking part in a procession, bathing or incubation. A case where we have reasonably good evidence is initiatory pilgrimage to the Great Mysteries in Attica. Similar patterns are found in Greco-Roman healing sanctuaries; see PetsalisDiomidis 2005, 198-205 on the "choreography" of Roman Pergamum.

- A feeling of communality with other pilgrims. The term most commonly used for this today is communitas, invented by Victor Turner who saw in it an almost mystical "antistructure" uniting all humanity (Turner 1972). Shared feeling happens particularly on the occasion of festivals, but it can be generated vicariously by seeing evidence for visits by other people at the sanctuary. In reality, it may be that by creating cohesion within one group, pilgrimage has the effect of accentuating differences between groups, either between different groups of pilgrims, or between pilgrims and other people. ${ }^{5}$

- The experience of the journey. In some religious traditions, emphasis is put on the journey to and from the sacred place, sometimes with the idea that the difficulty of the journey enhances its value. The experience of the journey is not well documented for Greco-Roman pilgrimage, though we know that "sacred ways" leading to the sanctuary were in some cases ritualized (cf. Pausanias 1.36-7 the journey from Athens to Eleusis). Sacred delegates

4 In a previous paper (Rutherford 2000) I argued that intense religious vision might have been part of this.

5 For an effective critique of communitas in the context of pilgrimage, see Kantner et al. 2012, $67-68$. 
(theōroi) sent by cities to festivals seem to have had a special sacred status en route (cf. Rutherford 2013, 174-178).

- Experience of the sanctuary-infrastructure. Key elements are: a. cult statues, sacred ways, hostels, dining rooms etc.; b. dedications by and records of previous pilgrims; c. pilgrimage-infrastructure, such as hostels and dining rooms. The visitors' experience of the sanctuary was not always positive: the Stoic philosopher Epictetus, as reported by Arrian (Discourses 6.1.10) talks about the inconvenience of Olympia:

Do you not swelter? Are you not cramped and crowded? Do you not bathe with discomfort? Are you not drenched when it rains? Do you not have your fill of tumult and shouting and other annoyances?

- Pilgrimage experienced as a rite of passage? Victor Turner also suggested that pilgrimage can function as, or symbolize, a rite of passage between different life-stages (Turner 1972). This model might work for some forms of pilgrimage in the ancient world; for example, initiation into the Eleusinian Mysteries, which takes place at the culmination of a pilgrimage, functions as a rite of passage between the status "non-initiate" and "initiate". 6

\section{Paideia and the Second Sophistic}

For educated pilgrims in the Second Sophistic, a more nuanced theory about the experience of pilgrimage has been proposed. It has been suggested that in this period sacred places were primarily lieux de mémoire; visiting them was thus an intellectual experience, but also triggered an emotional response for which visitors had already been primed from their paideia (literary education). Jas Elsner suggested that Pausanias was writing for these sorts of people, and indeed was this sort of pilgrim himself (Elsner 1992). This view was further developed in an important article by Marco Galli, e.g (Galli 2005, 258):

The interaction of mental images, already present in the observer, and their activation via emotional tensions generated by contact with a sacred place, constitute the catalyzing experience of the pilgrimage.

However, it would be a mistake to see these attitudes as confined to the Second Sophistic: it must have been common at all periods for visitors to approach the sanctuaries equipped with some knowledge about it sanctuary. For

6 For other examples, cf. Rutherford 2005. 
example, the chorus of Euripides' tragedy Ion who are Athenians visiting Delphi for the first time, are represented as already knowing something about the material culture of Delphi, and in the same play Creusa reacts in a complex way to it, comparing it with her own negative experiences of Apollo (247ff.).

Equally, experience conditioned by elite-paideiā was not necessarily typical of the Second Sophistic. The basis for this reconstruction is largely literary sources, such as Plutarch and Pausanias, who it could be argued are not describing pilgrimage at all, but elite intellectual tourism. Meanwhile, there were other traditions, such as the pilgrimage to the Syrian Goddess at Hierapolis-Membig in North Syria and that to the cult of Glycon at Abonoteikhou in Paphlagonia, both described by Lucian (Petsalis-Diomides 2010), which were presumably more popular in character, and lacking in elite paideiā.

For some sanctuaries, the clientele may have been a mixture, comprising a majority of ordinary people, and some members of the educated elite. Take, for example, the case of the so-called Memnonion at Abydos in Egypt, which was originally the mortuary temple of the pharaoh Seti I, but identified with the palace of Memnon, the Ethiopian hero of Greek epic, from the time of Strabo (Geog.17.1.42):

Above this city is Abydos, where is the palace of Memnon, constructed in a singular manner, entirely of stone, and after the plan of the Labyrinth, which we have described, but not composed of many parts. It has a fountain situated at a great depth. There is a descent to it through an arched passage built with single stones, of remarkable size and workmanship.

Strabo refers to the so-called Oseirion at the back of the Memnonion. His account is aimed at the educated elite and the reference to the "Labyrinth" ultimately recalls Herodotus' account of the so-called Labyrinth at Lake Moeris (see Lloyd 1970).

The walls of the main building preserve graffiti in honor of the deities Sarapis or Bes (the latter approached via a chapel at the back of the building) written by or on behalf of visitors over several centuries (see Rutherford 2003). It may be that for many of these the primary destination was the main temple of Osiris, which has not survived. Major motivations were healing and consulting the oracle of Bes (the political importance of which in the 4th century is attested by Ammianus Marcellinus, Hist. 19.12). Little can be said about the experience of these pilgrims, except that many of them came from the region and some of them underwent incubation (see Rutherford 2003, 182). Some of them inscribed graffiti, often including the proskunema formula, which announces the proskunèma ("adoration") of such and such a person besides the deity (see 
Geraci 1971). This may imply the physical act of proskunēsis or prostration before the deity.

Of learned self-reflective pilgrims there are very few signs:

1. In one graffito (PL498) ${ }^{7}$ the pilgrim Bagas speculates on the identity of the divinity, who he himself thinks of as Dionysus. ${ }^{8}$

2. Another graffito (PL563), records a visit by one Menelaos son of Dikaios to the "Memnonion", which shows knowledge of the tradition reported in Strabo (17.1.42).

3. The most "learned" artifact from the site seems to be a Greek poem which has been found inscribed on the wall of the Oseirion, composed apparently by two Italians passing through on their way home (Boyaval 1969). It is difficult to interpret, not least because only alternate lines survive, but it is clear that it is addressed to Maia, mother of Hermes in Greek tradition, presumably here identified with Hermes Trismegistos, who for Romans of this period would have been regarded as one of the most important Egyptian gods. Hermes is asked to help the dedicators in their journey as he had helped Odysseus in Homer's Odyssey.

But these three are not much out of a total of almost one thousand graffiti.

\section{Jewish pilgrimage and communitas}

One important pilgrimage tradition of the early Roman Empire that has often been neglected is that of Jewish pilgrimage to Jerusalem. ${ }^{9}$ Until the destruction of the Second Temple in $70 \mathrm{CE}$, thousands of pilgrims from Judea, Babylon and all over the Jewish Diaspora visited Jerusalem every year to celebrate the three main Jewish festivals: Passover (Pesach) in Nisan (April), the Feast of Weeks (Shavuot) in Sivan (June), roughly corresponding to Christian Pentecost, and Sukkot (Tabernacles) in Tishri (October). Attendance at these festivals is already prescribed in the Torah (although originally it applied only to pilgrimage from within Judea and Samaria). According to Greco-Jewish and Hebrew sources the numbers were huge. Josephus (Jewish War 6.420-7) in his discussion of the events of $70 \mathrm{CE}$ says that 2,700,000 people attended the Passover in

$7 \mathrm{PL}=\mathrm{P}$. Perdrizet and G. Lefebvre 1919.

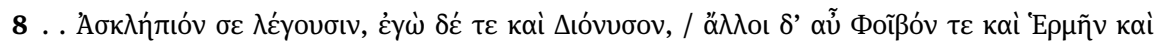
Артохра́тпv.

9 See Safrai 1981; Feldman 2006; Amir 1983; Rutherford 2017. 
that year; even if this number is hugely exaggerated, it was still a vast event. Martin Goodman has suggested that the practice was encouraged by Herod the Great for economic reasons (Goodman 1999).

The fullest discussion of pilgrimage to Jerusalem in an ancient writer, at least in Greek, is by the Jewish Alexandrian author Philo of Alexandria. For Philo both the city and the Temple of Jerusalem were unique. The Temple was the only place it was legitimate to worship Yahweh, and Jerusalem was the mother-city (mētropolis) of world Jewry (In Flacc. 46). Philo himself made the pilgrimage to Jerusalem at least once, but his brief reference to that journey in On Providence provides no insight into the significance of the experience ( $D e$ Prov. 2.64). His fullest account is in the Special Laws (1.67-70), an elaboration of the prescription regarding pilgrimage in the Torah. Since God provides that there is only one Temple, it is incumbent on people to go there to sacrifice:

Further, he does not consent to those who wish to perform the rites in their houses, but bids them rise up from the ends of the earth and come to this temple. In this way he also applies the severest test to their dispositions. For one who is not going to sacrifice in a religious spirit would never bring himself to leave his country and friends and kinsfolk and sojourn in a strange land (xeniteuein), but clearly it must be the stronger attraction of piety which leads him to endure separation from his most familiar and dearest friends who form as it were a single whole with himself (henōmenōn merōn). And we have the surest proof of this in what actually happens. Countless multitudes from countless cities come, some over land, others over sea, from east and west and north and south at every feast. They take the temple for their port as a general haven and safe refuge from the bustle and great turmoil of life, and there they seek to find calm weather, and, released from cares whose yoke has been heavy upon them from their earliest years, to enjoy a brief breathing space in scenes of general cheerfulness. Thus filled with comfortable hopes, they devote the leisure, as is their bounden duty, to holiness and the honoring of god. Friendships are formed between those who hitherto did not know each other and the sacrifices and libations are the occasion of reciprocity of feeling (literally a mixing (krāsis) of $\bar{e} t h \bar{e})$ and constitute the surest pledge of concord (homonoi $\bar{a}){ }^{10}$

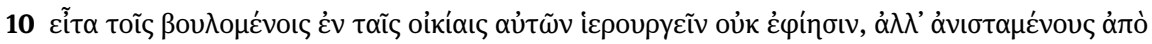

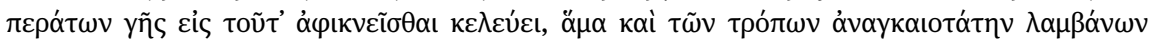

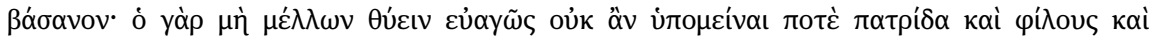

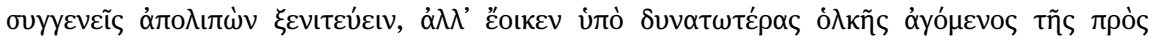

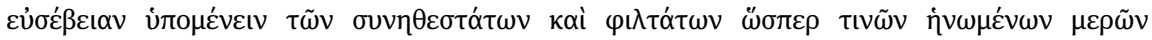

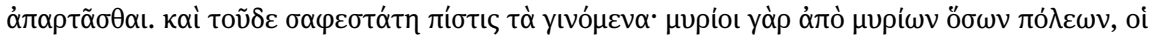

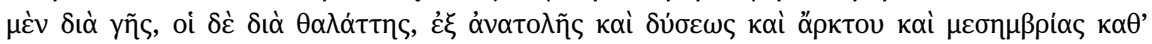

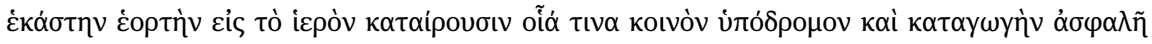

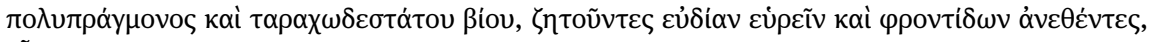

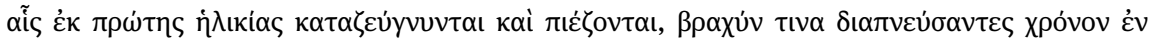

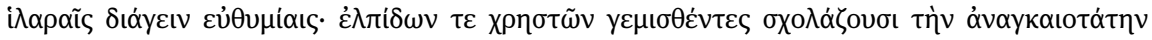


This text tells us a lot about the sociology and experience of the pilgrimage. ${ }^{11}$ There are three components, which combine the religious and the sociological:

i. first, leaving one's own community, as from a set of unified parts, so as to become a stranger abroad (xeniteuein). ${ }^{12}$

ii. second, calm, cheerfulness, leisure-devoted-to-religion; and

iii. third, becoming part of another community in Jerusalem: getting to know fellow Jews you did not know before, the mixing of $\bar{e} t h \bar{e}$ and the creation of homonoiā.

Philo's analysis is unique - nothing of this sort survives for Greco-Roman pilgrimage (although some of the ideas occur in philosophical analysis of festivals) (see Rutherford 2017). For Philo, religion itself plays a minor part, and learned paideia none at all; it is almost wholly sociological: the bodies of participants are torn from their ordinary social contexts and brought together to form a new, if temporary, body-politic. In fact, element iii. is very similar to Turner's communitas, a perceived leveling of differences between participants, resulting in a new social order which he called "antistructure". ${ }^{13}$ Perhaps it would be better to see the idealized community of the Jerusalem-pilgrimage as the authentic and underlying structure of the Jewish state, opposed to the unreal "antistructure" of the Diaspora. In any case, the idealized community of Jerusalem is an elite group, entirely separate from the mass of humanity.

\section{Claros: Paideiā as a rite of passage}

The best documented pilgrimage tradition from the Roman period is that relating to the cult of Apollo at Claros at Colophon. The oracle dates back at least to the 6th century CE, but it came to prominence in the Hellenistic and Roman periods, when it started to rival Didyma. It seems that the cult of Apollo Clarius

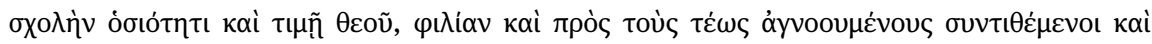

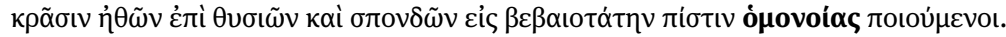

11 A few decades later, after the destruction of the temple in Jerusalem, Josephus gives an account very similar to Philo's (Jewish Antiquities 4.203-204).

12 The word xeniteia $\bar{a}$ is later used of the alienated life of monks: see Bitton-Ashkelony 2005, $147-151$ on the role of xeniteia and its Syrian equivalent askaniutha in early Christian pilgrimage; for the idea of the Christian pilgrim as an alien see also Pullan 2005, 394-395.

13 Communitas: Turner 1974 (an adapted version of Turner 1972); see also Feldman 2006. For an insightful critique of Victor and Edith Turner's religious development, see Larsen 2014, 174-220. 
was closely connected with the imperial cult, at least from the 2nd century CE (see Ferrary 2005; 2014). ${ }^{14}$

Almost all the evidence is epigraphical. Most of it is in the form of inscriptions displayed in the sanctuary documenting recording delegations. Several hundred of these survive covering a time span of over a century; they have recently been edited by Jean-Louis Ferrary. The delegations come from these main areas: Ionia and Aeolis; Macedonia and Thrace; the Black Sea; Northern Asia Minor; the Propontis; central Asia Minor; and Crete. The only delegation attested from mainland Greece is from Corinth. Some cities sent regular delegations (every year or every few years) over several decades; the most faithful clients are cities in SW Phrygia and NE Caria (e.g. Laodiceia on the Lycus) and Ionia (e.g. Chios). Secondly, we have verse-oracles from Claros which were displayed in the home cities of the consulters (Merkelbach and Stauber 1996), many of them responses to enquiries relating to plague. Most of the consulters come from Asia Minor, and almost all of them are cities. Sometimes the oracle seems to have ordered the sending of delegations. Light on the religious "network" of Clarian Apollo is also shed by two further data sets: first, a group of inscriptions which record dedications "in accordance with the exegesis of Clarian Apollo"; most of these come from the Western Roman Empire and are in Latin; only one Greek example survives, from Melli in Pisidia (Mitchell 2003). Secondly, one filial cult of Apollo Clarius is attested, from Sagalassos in Pisidia, which also sent delegations to Colophon; there may have been another at Apameia-Myrleia. Overall, the clientele of Claros seems to have been from Greek or Greco-Roman areas, although the theology of the oracle seems to be syncretic and to include some non-Greek elements, ${ }^{15}$ and, as has been noted, the oracle-authorities seems to have made a point of inviting barbaroi as well (see Robert and Robert 1989, 94-95).

A characteristic of the delegations is they include choirs of children (usually between six and fourteen in number; sometimes boys and girls, sometimes just boys) who sing hymns. In some cases the same individuals are known to have made several journeys, first as children and later as adults. The practice of sending choirs of young people to a sanctuary of Apollo recalls the festival culture of Delos in the 5th century BCE. It is rare in this period, though an inscription from Kaunos (1st century CE) attested a delegation of young men sent to Samothrace (Marek 2006, no. 28, 19). One learned feature of the inscriptions is

14 I discuss this further in Rutherford (forthcoming).

15 Cf. the verse oracles edited by Merkelbach and Stauber 1996, no. 25-28. Deities mention include Aither (no. 25), Aion (no. 26) and Iao (no. 28). 
that the language used (such as the words theorroi and the archaic sounding eitheoi ("young men") sometimes seems designed to recall descriptions of theōroi from earlier centuries. Hierapytna in Crete sends delegations of fourteen singers (seven girls, seven boys) which suggests the "Dis Hepta" ("Twice Seven") familiar from the Athenian myth of Theseus and the Minotaur.

The delegations to Claros often included a designated oracle consulter, the theopropos (sometimes more than one), who underwent initiation, followed by an action designated by the Greek verb embateuein, which seems to mean "stepping into". The prose introduction to the long oracle for Pergamum refers to those:

[... who being] initiated and 'ste[pping into', consulted the oracle and received t]he subscribed oracular response.

Three other documents also say that theopropoi were initiated, "stepped into" and consulted the oracle. It seems likely that both initiation and embateia are integral parts of the process of consultation, rather than independent ritual activities. Perhaps the "initiation" had something to do with the mystical, syncretistic religious doctrines for which Claros seems to have been known. These actions seem to have been followed by the giving of the oracle and its reception by the delegates, perhaps in an underground chamber (cf. Rutherford 2013, 101-102).

That, in rough outline, is all the information we have for the experience of pilgrims at Claros. Much is unknown, such as whether delegations visited on the occasion of a festival, so that delegations from different cities met. We have no information about performances, dance-styles etc. There is in the extant documentation no sign of communitas (perhaps a great communal hymn to Apollo?) or any other communication between pilgrims from different towns. We don't know whether other rituals were important also, such as animal sacrifice (an oracle from Didyma in the 3rd century BCE conveys the surprising information that Apollo prefers song to animal sacrifice) (see Rutherford 2013, 237). Nor do we know whether pilgrim-delegations coming all the way from central or even eastern Anatolia would have taken the opportunity to visit other famous sanctuaries in the West, such as Ephesos. It goes without saying that we have no information about how these young people felt to be removed from their home communities (like Philo's pilgrims), though we can guess.

It is reasonable to think that a major part of the effect of the pilgrimage was showing off to other people. Cities may have aimed to outdo each other at Claros, sending elaborate delegations which served to display their piety and wealth (cf. the model of "costly signals", which are effective because recognized as unlikely to be faked) (Henrich 2009; Kantner and Vaughn 2012). A clue 
to how this worked may be provided by a scene from Heliodorus' novel the Ethiopian Story (3rd-4th centuries CE) which describes the arrival of a large theōria from Thessaly at Delphi and the spectacular impression it made. In Heliodorus' narrative the leader of the delegation is presented as a Greek of unimpeachable ancestry, tracing his family back the family of Achilles whose son Neoptolemus was worshipped at Delphi (Heliodorus, Aithiopika 3.4-5; Rutherford 2013, 351-352); possibly similar networks of ethnicity and ancestry played a part in pilgrimage to Claros. Delegations to Claros may also have tried to make an impressive display in other places en route, especially since they passed through other cities that sent delegations to Claros (e.g. delegations from Iconium in Lycaonia will have passed through or close to the territory of Laodikeia in SW Phrygia).

For the young choreuts themselves, these trips could have been a formative experience. They will have learned about the traditions of the sanctuary and gained experience of the broader world of Greco-Roman culture beyond their own cities. It will also have trained them to present themselves in a specific way in public, as a coordinated group of young, paideiā-equipped members of the elite, representing their cities in public and displaying the cultural habitus that befitted their status. Finally, the whole process of travel to Claros and back again will probably have tended to confirm their elite status within their own communities. It could have been a key stage in their initiation to adult life, almost a rite of passage.

\section{Aristides and piety-signaling}

Probably the best source for the experience of pilgrimage in the Roman world is Aelius Aristides, a prominent embodiment of paideiā, who left detailed records of his religious life in his Sacred Tales. ${ }^{16}$ Aristides was a devotee of Asclepius of Pergamum, to whose will, as revealed through dream oracles, he seems to have outsourced responsibility for running his life. For Aristides, Asclepius, or more precisely Zeus-Asclepius, was not merely a healer but the "fairest, and most perfect torch-bearer and mystagogue" (Or. 23.16), terminology which suggests the teleological initiation of Eleusis. He also calls him "the One” (Sacred Tale 4.50), an epithet which perhaps suggests Isiac religion (see Dousa 2002).

16 The bibliography on Aristides is increasing all the time. I wrote about Aristides' minor pilgrimages in Rutherford 1999, and I have found particularly helpful the work of Alexia PetsalisDiomidis, e.g. Petsalis-Diomidis 2005; 2010. 
Aristides spent two years in the Asklepieion at Pergamum, during what he called the Kathedrā ("sitting") from 145 CE to 147 CE, and this period can be thought of as a sort of extended pilgrimage. Apart from those years, he seems to have been often on the move, making journeys that often resemble minipilgrimages. Finally, Aristides also dreams of sacred journeys: the Fifth Sacred Tale concludes with a dream in which he is transported to Athens, where he visits a temple of Plato (see below). In another dreams he is chased through a long tunnel, to arrive at Smyrna just at the moment when a choir there greets the sunrise (Sacred Tale 1.22).

Aristides' pilgrimages are motivated by healing, and as such they are rather different from, say, the pilgrimage to a national festival described by Philo, and from the sacred delegations to Claros (though health, at least public health, was a motivation in the case of at least some of those as well). In fact, Aristides knew of motivations for sacred travel besides healing-pilgrimage. When he sets off for the healing springs at Gönen on the River Aesepus (Sacred Tale 4.2) he says that he was in such a high spirits when they set out that it was "as if we were going to a festival ( $\dot{\omega} \varsigma$ cis $\theta \varepsilon \omega \rho i \alpha v)$ )" (it is significant that on this journey, he composes hymns, almost as if he is going to visit Claros); the phrasing here implies that normally healing pilgrimages were different from festival journeys. ${ }^{17}$ Similarly, Aristides motivation is not primarily paideia , although he is aware that intellectuals sometimes travel for this reason; for example the Cretan philosopher Euarestos who, as he relates, comes from Egypt to

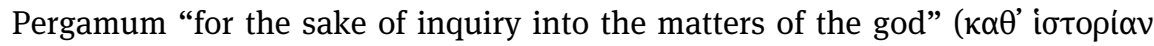

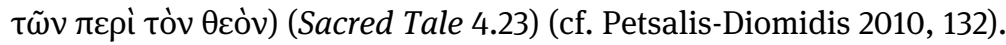

What can we say about his experience? His account is uniquely detailed, and he sheds light on aspects which are hardly mentioned in other sources, for example:

a. that ancient pilgrims sometimes had to battle with adverse conditions on the journey, e.g. because of the weather (for examples in Aristides, see Rutherford 1999, 136; Petsalis-Diomidis 2010, 108); similarly, that the god may sometimes be thought to supervise the journey. At Sacred Tale 5.26, the road towards the temple of Pergamum is marked by a streak of clear weather, while on the right it is snowy and on the left it is raining (cf. Petsalis-Diomidis 2010, 138-139). On another occasion a mini-procession within the sanctuary is led by two divinely-sent ducks (Sacred Tale 3.49). ${ }^{18}$

17 Note that $\theta \varepsilon \omega$ piav here means "festival/spectacle", not "pilgrimage" (Behr 1981) or "sacred embassy" (Rutherford 1999, 142).

18 Similarly, at Sacred Tale 5.18 a dream about the Clouds of Aristophanes warns him not to set out on what would turn out to be a rainy day. 
b. That the religious experience at the sanctuary is a very intense one. I have already mentions Aristides' account of his experience of Asclepius at Pergamum ("it seemed as if I touched him": Sacred Tale 2.32-33). Notice also his elation-coupled-with-anxiety at the culmination of the pilgrimage to the baths at Gönen on the Aesepus River at Sacred Tale 4.7:

It was all not only like an initiation into a mystery, since the rituals were so divine and strange, but there was also something coincidentally marvelous and unaccustomed. For at the same time there was gladness, and joy, and a contentment of spirit and body, and again, as it were, an incredulity that it will ever be possible to see a day when one will see himself free from such great troubles...

c. That the return is a critical moment: e.g. at Sacred Tale 4.10 Aristides records the propitious remarks he heard from children and others when he arrived back from his second pilgrimage to Gönen. This is followed by a ritual of sprinkling earth on himself, which is said explicitly to be a substitute for death and burial, i.e. a sort of rite of passage.

All three of these things may have been characteristic of many forms of pilgrimage in this period or earlier.

On the face of it, Aristides' experience of pilgrimage includes something like communitas. He has elite fellow incubants/pilgrims (sumphoitētai); ${ }^{19}$ in a well-known passage of On Concord he praises the Asklepieion as a second colony from Trikka, the first being Epidauros, and goes on:

No gathering of a chorus nor fellowship on board a ship nor having the same teachers is such a great thing as the benefit of going together (sumphoitēsai) to the temple of Asclepius and being initiated in the foremost rites by the fairest, and most perfect torchbearer and mystagogue, to whom every law of necessity yields ${ }^{20}$

19 A word first used by Herodotus (Hist. 2.60) in the context of pilgrimage to Bubastis in Egypt. Cf. Petsalis-Diomidis 2010, 222: "although they may have travelled alone or accompanied by relatives or close friends, on arriving at the sanctuary those who came to consult Asklepios became part of a visible group of pilgrims to the god, and performed a variety of rituals en masse".

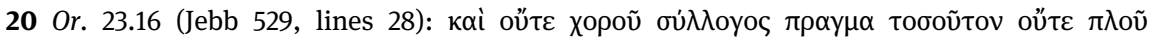

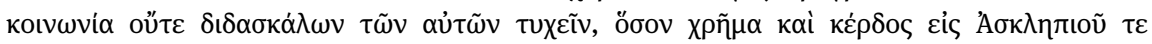

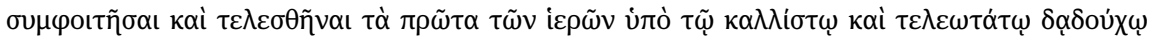

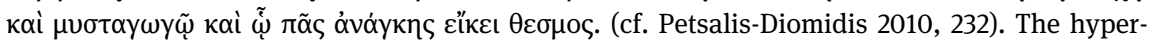

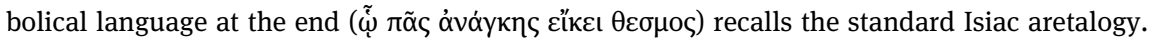
For Egyptian religion at Pergamum, see the papers in Hoffmann 2005. 
So in Sacred Tale 2 he dreams he shares sacrificial meat with the sumphoitetai (2.27) and that he is one of a group of white-robed men standing before the Propyleia of the temple (2.31; cf. 2.30). In fact, however, this pretense of communitas breaks down in the face of Aristides' claim to personal exceptionalism. ${ }^{21}$ In another dream, a vision of communitas - a group of pilgrims worshipping Asclepius in person - is immediately undercut when Asclepius singles him out for praise (Sacred Tale 4.50).

First, the cult statue seemed to have three heads, and to shine about with fire, except for the heads. Next we worshippers stood by it, just as when the paean is sung, I almost amongst the first. At this point the god, in the posture in which he is represented in the statues, signaled our departure. All the others were going out, and I was turning to go out, and the god, with his hand, indicated for me to stay. And I was delighted by the honour and the extent to which I was preferred to the others, and I shouted out 'The One', meaning the god. But he said 'It is you'. ${ }^{22}$

Elsewhere he imagines the community of the Asklepieion as a panēguris consisting of prominent Greeks who come to see him in his tribulations (Sacred Tale 1.65). ${ }^{23}$ In Aristides' self-centered universe, the only form of communitas that matters is that of an audience united in paying attention to him. Or perhaps we might say that the only people he thinks of as in the same class as him are great figures of Greek literature and culture; thus at Sacred Tale 4.24 Asclepius tells him which authors to read and henceforth they become his comrades (hetairoi).

This brings us back to the issue of paideia. Aristides was certainly aware that in his time members of the elite used to visit sanctuaries to engage in Greek cultural traditions. Consider for example the narrative of his dream visit to the imaginary temple of Plato in Athens, where he holds forth on the date of the statue of Plato in a very pepaideumenos manner (Sacred Tale 5.61):

When I reached the entrance, I saw that it was a temple of Plato, the philosopher, and that a great and fair image was erected to him there, and a statue of someone was erected

21 There is an unambiguous illustration of this at Sacred Tale 4.49, where he dreams the he is proclaimed Olympic victor and is buried next to Alexander the Great. Another example is his statement in the Lalia to Asclepius (Or. 42.6-7) that Asclepius has given him his whole body (whereas to other people he gives at most part of his body).

22 For Aristides as a god, see Sacred Tale 1.17: a statue of Asclepius seems to be a statue of Aristides.

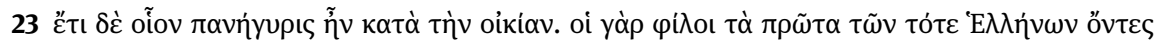

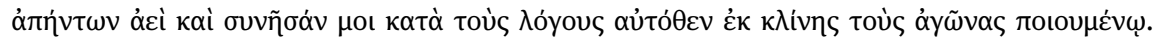
On another occasion people going to attend a festival in Pergamum turn back to Ephesos when Aristides passes them going in the other direction (Sacred Tale 2.81; cf. Petsalis-Diomidis 2010, 139). 
on his right. A very beautiful woman sat upon the threshold and spoke about Plato and the statue. Some others also took part in the discussion, and at the same time spoke about it as if it were ancient. And I said about it: 'it is not possible to say that it is ancient. For the form of the workmanship is shown to be somewhat recent, and there was not much regard for Plato in his lifetime, but, I said, his reputation grew later ....

But we should not necessarily infer from dreams such as this that his own behavior in sanctuaries was serene and contemplative in the same way.

Certainly, paidei $\bar{a}$ permeates Aristides' experience in the Pergamene Asklepieion: it is not only that he associates with educated people there, but also that he uses them as a practice audience, making demonstration speeches and organizing artistic performances. Asclepius actually encourages his to take up oratory again after a lapse caused by illness, and to make a "first fruit offer-

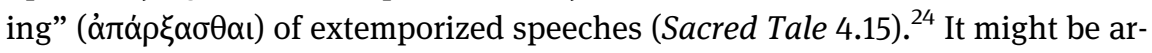
gued, then, that in so far as for Aristides normal health implies the ability to practice as an orator, the form of healing he seeks and ultimately receives from Asclepius at Pergamum is at least in part an intellectual one, and the Asklepieion, which was an international cultural center as well as a sanatorium, was thus the perfect place to provide it.

But a different picture emerges if we consider the minor religious journeys or pilgrimages he makes. Key factors seem to be (a) his relationship with the deity, the meaning of whose instructions he sometimes seeks to discover en route; (b) the difficulties posed by the weather and the natural landscape (see Brink 2016); and (c) the suffering of his own body, sometimes accentuated by the journey, and by the rituals which he is obliged to perform, often in full view of an audience. A good example is the mini-pilgrimage which happened in 149 CE (Sacred Tale 2.11ff.), when Aristides was instructed to leave Pergamum and go to the island of Chios for a purgation. On embarking at Clazomenae to make the sea-trip to Chios, a storm occurs, and the boat is driven East to Phokaia instead, where he undergoes the purgation and performs a mock shipwreck. He spends three days at a place called Geneais. There is also an encore: Asclepius leads him to Smyrna, where he has a complex vision (described as an epiphaneiā) of Asclepius, Apollo of Claros and Apollo Kalliteknos of Pergamum, and then a freezing bath in the river Meles in front of a crowd of people (Sacred Tale 2.19-21):

This is a summary of the divine manifestations (epiphaneiai), and I would place a high premium on being able to recount exactly each particular of it. It was the middle of winter, and the north wind was stormy and it was icy-cold, and the pebbles were fixed to one

24 For "first fruits" applied to verbal contests, cf. the language of Athenian decrees at Delphi: Rutherford 2013, 114 n. 29. 
another by the frost so that they seemed like a continuous sheet of ice, and the water was such as is likely in such weather. When the divine manifestation (epiphaneiā) was announced friends escorted us and various doctors, some of them acquaintances and those who came either out of concern or even for the purpose of investigation ... When we reached the river there was no need for anyone to encourage us. But, being still full of warmth from the vision of the god, I cast off my clothes, and, not wanting a massage, I flung them where the river was deepest. Then as in a pool of very gentle and tempered water I passed my time swimming all about and splashing myself all over. When I came out, all my skin had a rosy hue, and there was a lightness throughout my body. There was also much shouting from those present and from those coming up, shouting the celebrated phrase, 'Great is Asclepius'.

There are touches of paideiā here: the threefold identity of the deity, and the river Meles, associated with Homer and therefore appropriate for a wordsmith. There is no sign of communitas, except on the part of the audience. The focus is on the ritual performance, almost a form of public virtue signaling, and on Aristides' reactions: his suffering at the beginning, his contentment at the end. The emergence of his body from the water at the end suggests a sort of climactic epiphany, and it is as if the chant "Great is Asclepius" was directed towards him. ${ }^{25}$ Just as overcoming suffering is a sign of religious presence, so submitting oneself to suffering itself approaches the status of a religious act.

This combination of deliberate self-punishment and salvation is striking. Judith Perkins has drawn attention to parallels to Aristides' suffering in accounts of the death of Christian martyrs, such as St. Blandina of Lyon and Ignatius of Antioch (although there is an important difference in that martyrs die, whereas Aristides recovers). ${ }^{26}$ That might suggest that this is a phenomenon of the early Roman Empire, although it is possible that this is a false impression created by the lack of evidence for personal pilgrimage in the preceding centuries. ${ }^{27}$ The best parallels may in fact be in initiation-rituals,

25 For slippage between Asclepius and Aristides, see Sacred Tale 1.17, cited earlier.

26 Perkins 1995, 180-181; for the general point, see p. 173: "Narrative issuing from different cultural points ... brought into cultural consciousness a representation of the human self as a body in pain, a suffering body." See also Perkins 1992: "If, as Foucault has suggested, the body is the site of all control, the Orationes sacrae relocates control, not to the self, the contemporary society, or the political structures, but to the realm of the transcendent. Part of the discursive project of the Orationes sacrae is a radical relocation of power from the earthly realm to the divine."

27 Petridou 2017, 137-138 argues against the "Foucauldian" thesis that the body and the self emerge as center stage in the Second Sophistic, suggesting instead that interest in the body in the Second Sophistic is a "natural progression of embodying and further embellishing trusted and time-resistant ideas about the body as a whole when healthy, fragmented when ill, and safe at critical moments in life only when it is in the vicinity of the gods". 
which often seem to have involved physical suffering and sometimes even mutilation (as in the case of the cult of the Magna Mater, whose acolytes were believed to castrate themselves: Burkert 1987, 102-104; Burkert 2004, 104-105).

\section{Conclusion}

To sum up, pilgrimage in the Roman Empire came in many forms, and the pilgrims' experience must have varied greatly as well. In this paper, I have pointed to three case studies, each of which seems to involve a different form of subjective experience, and each of which can be correlated with a different treatment of the pilgrims' bodies. In Philo's account of Jewish pilgrimage, members of the Jewish Diaspora are removed from their present environment and brought together in Jerusalem to form a temporary "body" of Jewish citizenry; even after they return home, the memory of this broader identity presumably persists. In the case of Claros, participation in a broader Greek or Roman identity with its focus in the sanctuary is probably also a factor, but the emphasis is on training groups of young people to perform together in public, representing their city and acting as its united external face; I have suggested that taking part in these sacred missions would have been a formative experience for the children involved, with cognitive and behavioral consequences: they learned about Greco-Roman culture (paideiā), but they also learned how to present themselves as elite citizens.

Aristides' healing pilgrimages share some general features with both of these. As pilgrimage to Jerusalem transforms the social lives of those who take part in it, the Kathedra at Pergamum provides a new community for Aristides, consisting in this case of members of the educated elite. However, Aristides is too unique an individual for this to be a stable communitas. There are also similarities between his pilgrimages and the delegations sent to Claros: like those, Aristides' pilgrimages were a response to oracular instruction (attested at least sometimes in the Clarian dossier); and they were public performances of ritual scripts, which communicated the pilgrim-performer's reverent attitude towards the deity. What is different about Aristides is that the elation of divine contact alternates with, and is facilitated by physical suffering and self-abasement, something which, as we saw, seems to be characteristic of the period. In the case of Aristides' pilgrimages, the suffering and elation seem to be mapped onto the journey and the arrival, a pattern with a long future in Christian pilgrimage. 


\section{Bibliography}

Amir, Yehoshua 1983. 'Die Wallfahrt nach Jerusalem in Philons Sicht.' In Die hellenistische Gestalt des Judentums bei Philon von Alexandrien, ed. Yehoshua Amir. Forschungen zum jüdisch-christlichen Dialog 5. Neukirchen. 52-64.

Behr, Charles A. 1981. Aelius Aristides: The Complete Works. Volume 2. Leiden.

Bitton-Ashkelony, Brouria 2005. Encountering the Sacred: The Debate on Christian Pilgrimage in Late Antiquity. Berkeley.

Boyaval, Bernard 1969. 'Graffite grec de l'Osireion d'Abydos', Chronique d'Égypte 44. 353-359.

Bremmer, Jan 2017. 'Pilgrimage Progress'. In Excavating Pilgrimage: Archaeological Approaches to Sacred Travel and Movement from Classical Greece to Late Antiquity, ed. Wiebke Friese, Troels Myrup Kristensen. Abingdon. 275-284.

Brink, Lineke 2016. Ill on the Road. Aelius Aristides' Pilgrimages from the Perspective of Landscape, Movement and Narrative. Masters Thesis, Leiden. openaccess.leidenuniv.nl/ handle/1887/42600.

Burkert, Walter 1987. Ancient Mystery Cults. Cambridge.

Burkert, Walter 2004. s.v. '3.c. Initiation', ThesCRA 2. 91-124.

Dillon, Matthew 1997. Pilgrims and Pilgrimage in Ancient Greece. London.

Dousa, Thomas M. 2002. 'Imagining Isis: On Some Continuities and Discontinuities in the Image of Isis in Greek Isis Hymns and Demotic Texts', Acts of the Seventh International Conference of Demotic Studies, Copenhagen, 23-27 August 1999. Copenhagen. 149-184.

Elsner, Jas 1992. 'Pausanias: A Greek Pilgrim in the Roman World', Past \& Present 135. 3-29.

Elsner, Jas 1997. 'The Origins of the Icon: Pilgrimage, Religion and Visual Culture in the Roman East as "Resistance" to the Centre.' In The Early Roman Empire in the East, ed. Susan E. Alcock. Oxford. 178-199.

Elsner, Jas; Rutherford, lan (eds) 2005. Seeing the Gods: Patterns of Pilgrimage in GrecoRoman and Early Christian Antiquity. Oxford.

Feldman, Jackie 2006. “A City that Makes All Israel Friends”: Normative Communitas and the Struggle for Religious Legitimacy in Pilgrimages to the Second Temple.' In A Holy People: Jewish and Christian Perspectives on Religious and Communal Identity, ed. Marcel Poorthuis, Joshua Schwartz. Leiden. 109-126.

Ferrary, Jean-Louis 2005. 'Les mémoriaux de délégations du sanctuaire oraculaire de Claros et leur chronologie', Comptes rendus des séances de l'Académie des Inscriptions et BellesLettres. 719-776.

Ferrary, Jean-Louis 2014. Les mémoriaux de délégations du sanctuaire oraculaire de Claros, d'après la documentation conservée dans le Fonds Louis Robert. Paris.

Galli, Marco 2005. 'Pilgrimage as Elite Habitus: Educated Pilgrims in Sacred Landscape During the Second Sophistic.' In Seeing the Gods: Patterns of Pilgrimage in Greco-Roman and Early Christian Antiquity, ed. Jas Elsner, Ian Rutherford. Oxford. 253-290.

Geraci, Giovanni 1971. 'Ricerche sul Proskynema', Aegyptus 51. 3-211.

Goodman, Martin 1999. 'The Pilgrimage Economy of Jerusalem in the Second Temple Period.' In Jerusalem: Its Sanctity and Centrality, ed. Lee Levine. New York. 69-76.

Henrich, Joseph 2009. 'The Evolution of Costly Displays, Cooperation and Religion: Credibility Enhancing Displays and their Implications for Cultural Evolution', Evolution and Human Behavior 30. 244-260. 
Hoffmann, Adolf (ed.) 2005. Aegyptische Kulte und ihre Heiligtümer im Osten des Römischen Reiches. Byzas 1. Istanbul.

Kantner, John; Vaughn, Kevin J. 2012. 'Pilgrimage as Costly Signal: Religiously Motivated Cooperation in Chaco and Nasca', Journal of Anthropological Archaeology 31. 66-82.

Kristensen, Troels M. 2012. 'Textiles, Tattoos and the Representation of Pilgrimage in the Roman and Early Christian Periods', HEROM 1. 107-134.

Kötting, Bernhard 1950. Peregrinatio religiosa: Wallfahrten in der Antike und das Pilgerwesen in der alten Kirche. Forschungen zur Volkskunde 33, 34, 35. Regensberg-Münster.

Labarre, Guy; Taslialan, Mehmet 2002. 'La dévotion au dieu Men: les reliefs rupestres de la voie sacrée.' In Actes du 1er Congres International sur Antioche de Pisidie, ed. Thomas Drew Bear, Mehmet Taslialan, Christine M. Thomas. Lyon. 257-312.

Larsen, Timothy 2014. The Slain God: Anthropologists and the Christian Faith. Oxford. Lloyd, Alan B. 1970. 'The Egyptian Labyrinth', Journal of Egyptian Archaeology 56. 81-100. Marek, Christian 2006. Die Inschriften von Kaunos. Munich.

McCorriston, Joy 2011. Pilgrimage and Household in the Ancient Near East. Cambridge.

Merkelbach, Reinhold; Stauber, Josef 1996. 'Die Orakel des Apollon von Klaros', Epigraphica Anatolica 27.1-54.

Mitchell, Stephen 2003. 'Inscriptions from Melli (Kocaaliler) in Pisidia', Anatolian Studies 53. 139-159.

Oster, Richard E. 1990. 'Ephesus as a Religious Center under the Principate. I. Paganism before Constantine', Aufstieg und Niedergang der römischen Welt 18.3. 1661-1728.

Perdrizet, Paul; Lefebvre, Gustave 1919. Les graffites grecs du Memnonion d' Abydos. Nancy.

Perkins, Judith 1992. 'The "Self" as Sufferer', Harvard Theological Review 8. 245-272.

Perkins, Judith 1995. The Suffering Self: Pain and Narrative Representation in the Early Christian Era. London.

Petridou, Georgia 2017. 'Introduction: Lived Ancient Religion and the Body', Religion in the Roman Empire 3. 137-142.

Petsalis-Diomides, Alexia 2005. 'The Body in Space: Visual Dynamics in Graeco-Roman Healing Pilgrimage.' In Seeing the Gods: Patterns of Pilgrimage in Greco-Roman and Early Christian Antiquity, ed. Jas Elsner, Ian Rutherford. Oxford. 183-218.

Petsalis-Diomidis, Alexia 2010. Truly beyond Wonders: Aelius Aristides and the Cult of Asklepios. Oxford.

Price, Simon 2012. 'Religious Mobility in the Roman Empire', Journal of Roman Studies 102. 1-19.

Pullan, Wendy 2005. 'Intermingled Until the End of Time: Ambiguity as a Central Condition of Early Christian Pilgrimage.' In Seeing the Gods: Patterns of Pilgrimage in Greco-Roman and Early Christian Antiquity, ed. Jas Elsner, Ian Rutherford. Oxford. 387-409.

Robert, Louis; Robert, Jeanne 1989. Claros I: Décrets hellénistiques. Paris.

Rutherford, Ian 1999. 'To the Land of Zeus: Patterns of Pilgrimage in Aelius Aristides', Aevum Antiquum 12.133-148.

Rutherford, Ian 2000. 'Theoria and Darshan: Pilgrimage as Gaze in Greece and India', Classical Quarterly 50.133-146.

Rutherford, Ian 2003. 'Pilgrimage in Greco-Roman Egypt: New Perspectives on Graffiti from the Memnonion at Abydos.' In Ancient Perspectives on Egypt, ed. Roger Matthews, Cornelia Roemer. London. 171-189. 
Rutherford, Ian 2005. 'In a Virtual Wild Space: Pilgrimage and Rite de Passage from Delphi from Sabarimalai.' In Greek Ritual Poetics, ed. Dimitrios Yatromanolakis, Panayotis Roilos. Cambridge, MA. 323-338.

Rutherford, Ian 2013. State-Pilgrims and Sacred Observers: A Study of Theoria and Theoroi. Cambridge.

Rutherford, Ian 2017. 'Concord and communitas: Themes in Philo's Account of Jewish Pilgrimage.' In Journeys in the Roman East: Imagined and Real, ed. Maren R. Niehoff. Tübingen. 257-272.

Rutherford, Ian (forthcoming). 'Towards a Typology of Sanctuary Networks: the Case of Claros.' In La cité interconnectée: transferts et réseaux institutionnels, religieux et culturels aux époques hellénistique et imperial, ed. Madeline Dana, Ivana SavalliLestrade.

Safrai, Shmuel 1981. Die Wallfahrt im Zeitalter des Zweiten Tempels. Neukirchen-Vluyn.

Totti, Maria 1985. Ausgewählte Texte der Isis- und Sarapis Religion. Subsidia Epigraphica 12. Hildesheim.

Turner, Victor 1972. 'The Center Out There: Pilgrim's Goal', History of Religions 12. 191-230. Turner, Victor 1974. 'Pilgrimages as Social Processes.' In Dramas, Fields and Metaphors: Symbolic Action in Human Society. Cornell. 166-230. 